\title{
Establishment and molecular characterization of a human ovarian clear cell carcinoma cell line (FDOV1)
}

Wei Jiang ${ }^{1,3+}$, Shuang $\mathrm{Ye}^{1,3+}$, Libing Xiang ${ }^{1,3}$, Wentao Yang ${ }^{2,3}$, Tiancong He $\mathrm{e}^{1,3}$, Xuan Pei ${ }^{1,3}$, Lin Guo 3,4 and Huijuan Yang ${ }^{1,3^{*}}$ (D)

\begin{abstract}
Background: Ovarian clear cell carcinoma is a distinct histologic subtype with grave survival. The underlying molecular mechanism is not fully elucidated. However, we don't have many cell lines, which are useful experimental tools for research. We describe the establishment and characterization of a new ovarian clear cell carcinoma cell line from a Chinese patient.

Results: FDOV1 has been subcultured for more than 80 generations. Monolayer cultured cells are polygonal in shape, showing a transparent cytoplasm full of vacuoles. The number of chromosomes ranges from 45 to 90. FDOV1 cells produces CA-125, but not CA-199. The cells could be transplanted and produced tumors mimicking the donor tumor morphologically and immunohistochemically. Whole exome sequence showed both FDOV1 and tissue block harbored PIK3CA H1047R mutation and ARID1A frameshift mutations (p.L2106 fs, p.N201 fs). More interestingly, we observed SPOP mutation (p.D82H) and ZNF217 (chromosome 20q13) amplification in FDOV1, which are quite novel.

Conclusions: Only a few patient-derived ovarian clear cell carcinoma cell lines have been reported in the literature. FDOV1 is the very first one, to the best of our knowledge, from a Mainland Chinese patient. It showed infinite multiplication until now and tumorigenicity in vivo. FDOV1 has co-existing PIK3CA and ARID1A mutations. It also harbored SPOP mutation and ZNF217 amplification, which would probably be a good model for exploring the molecular mechanism of ovarian clear cell carcinoma.
\end{abstract}

Keywords: Ovarian clear cell carcinoma, Cell line, FDOV1, ARID1A, PIK3CA, SPOP, ZNF217 amplification

\section{Background}

Epithelial ovarian carcinoma is the most lethal gynecologic malignancy. Ovarian clear cell carcinoma (OCCC) is the second most common histologic subtype, accounting for $5-25 \%$ of all ovarian cancer depending on geographic location $[1,2]$. It is well acknowledged that OCCC is more commonly seen in Asia women [3, 4]. OCCC represents a great challenge due to its disease aggressiveness and chemotherapy resistance. The grave survival and lack of

\footnotetext{
* Correspondence: huijuanyang@hotmail.com

'Wei Jiang and Shuang Ye contributed equally to this work

'Department of Gynecologic Oncology, Fudan University Shanghai Cancer Center, Shanghai 200032, China

${ }^{3}$ Department of Oncology, Shanghai Medical College, Fudan University,

Shanghai 200032, China

Full list of author information is available at the end of the article
}

effective treatment prompt us to investigate the underlying molecular mechanism of OCCC.

The two most widely reported gene mutations in OCCC are AT-Rich Interactive Domain-containing protein 1A (ARID1A) and Phosphoinositide-3-kinase Catalytic Alpha (PIK3CA), representing around 50\% [5, 6] and $40 \%[7,8]$ of all cases, respectively. Further studies supported that loss of ARID1A expression frequently coexisted with PIK3CA mutations [9]. What's more, coexistent ARID1A-PIK3CA mutations might promote ovarian clear cell tumorigenesis through synergic effects $[10,11]$. The breakthrough finding of ARID1A mutation has renewed the interest in elucidating the molecular pathways of OCCC [2], which still remains less well-understood than that of high-grade serous carcinoma.

(c) The Author(s). 2018 Open Access This article is distributed under the terms of the Creative Commons Attribution 4.0 International License (http://creativecommons.org/licenses/by/4.0/), which permits unrestricted use, distribution, and reproduction in any medium, provided you give appropriate credit to the original author(s) and the source, provide a link to the Creative Commons license, and indicate if changes were made. The Creative Commons Public Domain Dedication waiver (http://creativecommons.org/publicdomain/zero/1.0/) applies to the data made available in this article, unless otherwise stated. 
Cancer cell lines are affordable models for genetic and molecular profiles, reflecting the characteristics of the origin tumor. According to documentations till now, 16 OCCC cell lines were established and their characteristics have been reported [12-25], added ES-2 and TOV-21G, two commercial available cell lines, which characteristics and genetic features were obtained from ATCC database (http://www.atcc.org) and COSMIC database (https://cancer.sanger.ac.uk/cell_lines), respectively. The majority of the established cell lines were derived from Japanese patients. Besides, only one OCCC cell line TOV-21G was found with PIK3CA and ARID1A mutation. We describe here the establishment and characterization of a novel cell line (FDOV1) from a Chinese patient that harbors coexistent ARID1A-PIK3CA mutations.

\section{Results}

\section{Morphology and growth characteristics}

Up to now, more than 80 serial passages have been carried out successively. FDOV1 cells grew in the form of an adherent monolayer without contact inhibition (Fig. 1). Several types of cells were noted: small round cells, oval cells, polygonal spindle cells and irregular cells. The cytoplasm was characteristic of transparency and vacuolation.

The cell growth curve was shown in Fig. 2. The population doubling time was $37.4 \mathrm{~h}$, which was consistent with the low proliferation rate of OCCC. On flow cytometry analysis (Fig. 3), the cell cycle was distributed as: G1 phase, $42.3 \%$; G2 phase, $36.1 \%$; S phase, $21.6 \%$.

\section{Chromosomal analysis}

A total of 45 metaphase cells from FDOV1 were examined for chromosome analysis. Chromosome numbers ranged from 45 to 90 (Fig. 4). The following karyotypes

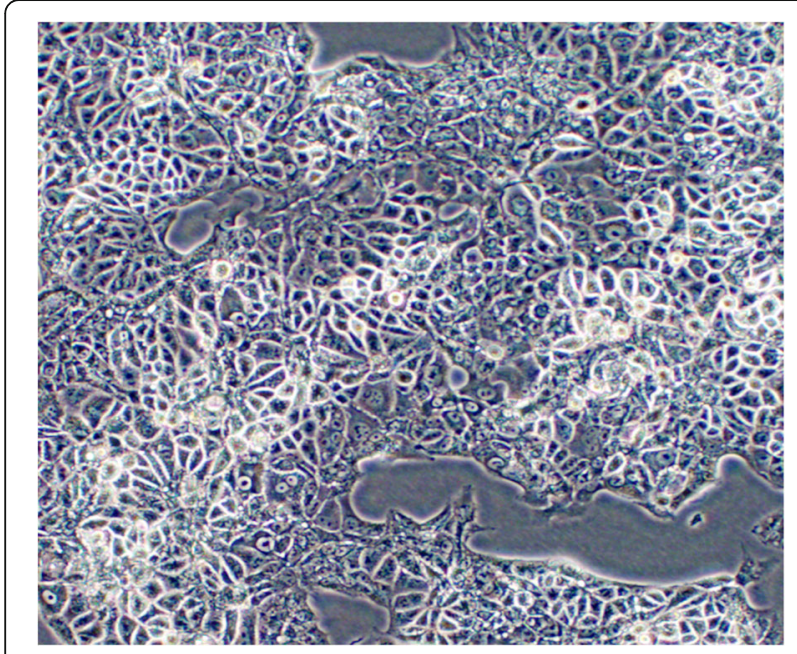

Fig. 1 Phase contrast microscopy (magnification $\times 100$ )

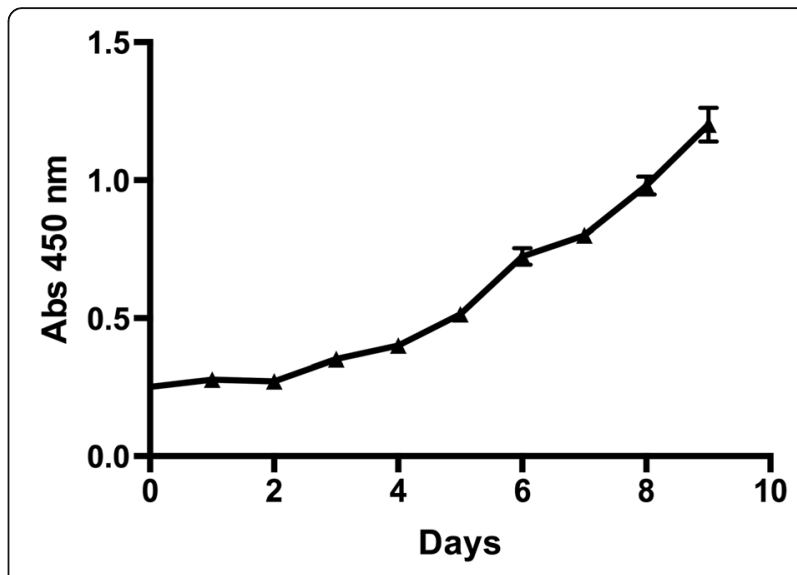

Fig. 2 Growth curve of FDOV1 (15th generation)

were observed: $2 n=45 / 46(35,78 \%) ; 2 n=47(3,7 \%)$; $4 n=86-90(6,13 \%)$. Chromosomal aberrations including complex translocations and deletions were noted, which were consistent with that of malignant tumors.

\section{Tumor markers}

The results for tumor marker measurement were listed as follow: CA125, $33.7 \mathrm{U} / \mathrm{ml}$; CA199, $0.78 \mathrm{U} / \mathrm{ml}$; CA153, $<1.00 \mathrm{U} / \mathrm{ml}$; CA724, $2.96 \mathrm{U} / \mathrm{ml}$; AFP, $<0.61 \mathrm{ng} / \mathrm{ml}$; CEA, $0.21 \mathrm{ng} / \mathrm{ml} ; \mathrm{HE} 4,<15 \mathrm{pmol} / \mathrm{L}$.

\section{Heterotransplantation}

To determine tumorigenicity, FDOV1 cells were injected into the dorsal flanks of two mice. Both mice developed visible tumors 20 days after injection. Fig. 5 presents the magnetic resonance imaging (MRI) of transplanted tumors of two mice 40 days after transplantation.

\section{Histopathology and immunohistochemical staining}

As clearly seen from Fig. 6, the xenografts morphologically mimicked the primary tumor in HE staining. Both the transplant and donor tumors showed diffuse intensive positivity for HNF-1 $\beta$ and Pax-8. Besides, negative Napsin A, ER and PR were observed for both tumors (results not presented).

\section{WES and sanger sequencing results}

We performed WES on FDOV1 cell, patient's tissue block and peripheral blood. It was reported that the tumor purity of FDOV1 cells achieved 100\% approximately, and that of the tumor block was $73 \%$, which is fit for investigating the molecular aberrations, including single nucleotide variant (SNV), insertion and deletion (indel) and copy number variation $(\mathrm{CNV})$. From the SNV related to cancer, it is shown that the tissue block and FDOV1 cell line shared some same somatic variations although diverse allele frequency (Fig. 7a). Interestingly, both tissue block and FDOV1 harbored PIK3CA 


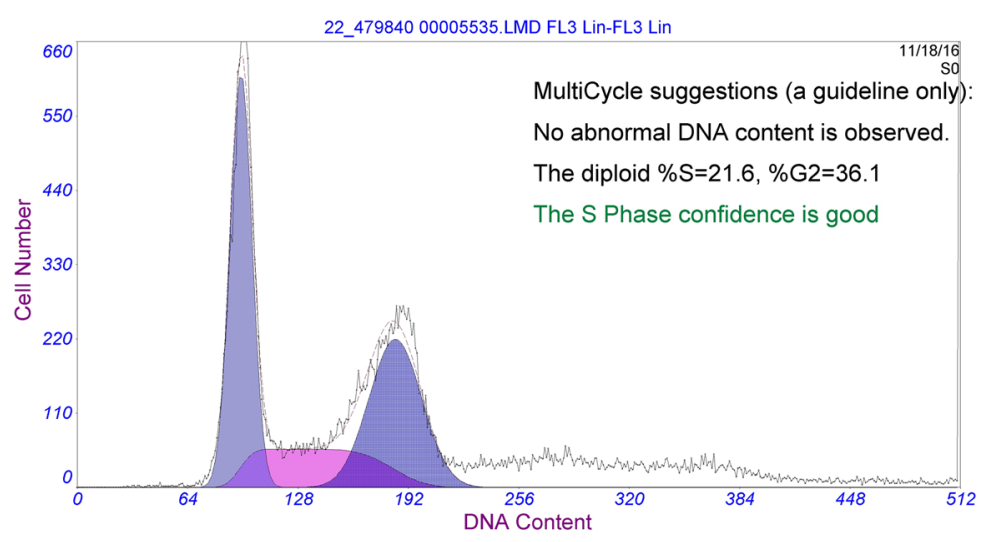

CELL CYCLE

DATA

Mean G1 $=96.108$

CV G1 $=6.633$

$\% \mathrm{G} 1=42.275$

Mean G2 $=185.726$

$\mathrm{CV} \mathrm{G} 2=8.185$

$\% \mathrm{G} 2=36.101$

$\% S=21.623$

\begin{tabular}{|c|c|c|c|c|}
\hline $\begin{array}{l}\text { Model } \\
\text { S0 } \\
\text { Sliced Bkgd } \\
\text { G2/G1 Fixed } \\
\text { Aggregates } \\
\text { SOrder=1 } \\
\text { CVS Fixed } \\
\text { [SO BADs]: }\end{array}$ & $\begin{array}{r}\text { Chis } \\
2.814 \\
2.920 \\
4.219 \\
2.902 \\
2.750 \\
3.976 \\
\text { BAD }=0.00\end{array}$ & $\begin{array}{l}\text { Dip S } \\
21.623 \\
21.367 \\
25.561 \\
21.381 \\
23.585 \\
23.679\end{array}$ & $\begin{array}{l}\text { Dip G2 } \\
36.101 \\
36.360 \\
32.464 \\
36.351 \\
33.422 \\
33.857\end{array}$ & $\begin{array}{l}\mathrm{G} 2 / \mathrm{G} 1=1.932 \\
\text { Chi Sq. }=2.814 \\
\text { Cell No. }=32138 \\
\% \text { Debris }=-1.000\end{array}$ \\
\hline
\end{tabular}

Fig. 3 Cell cycle of FDOV1 by flow-cytometry analysis
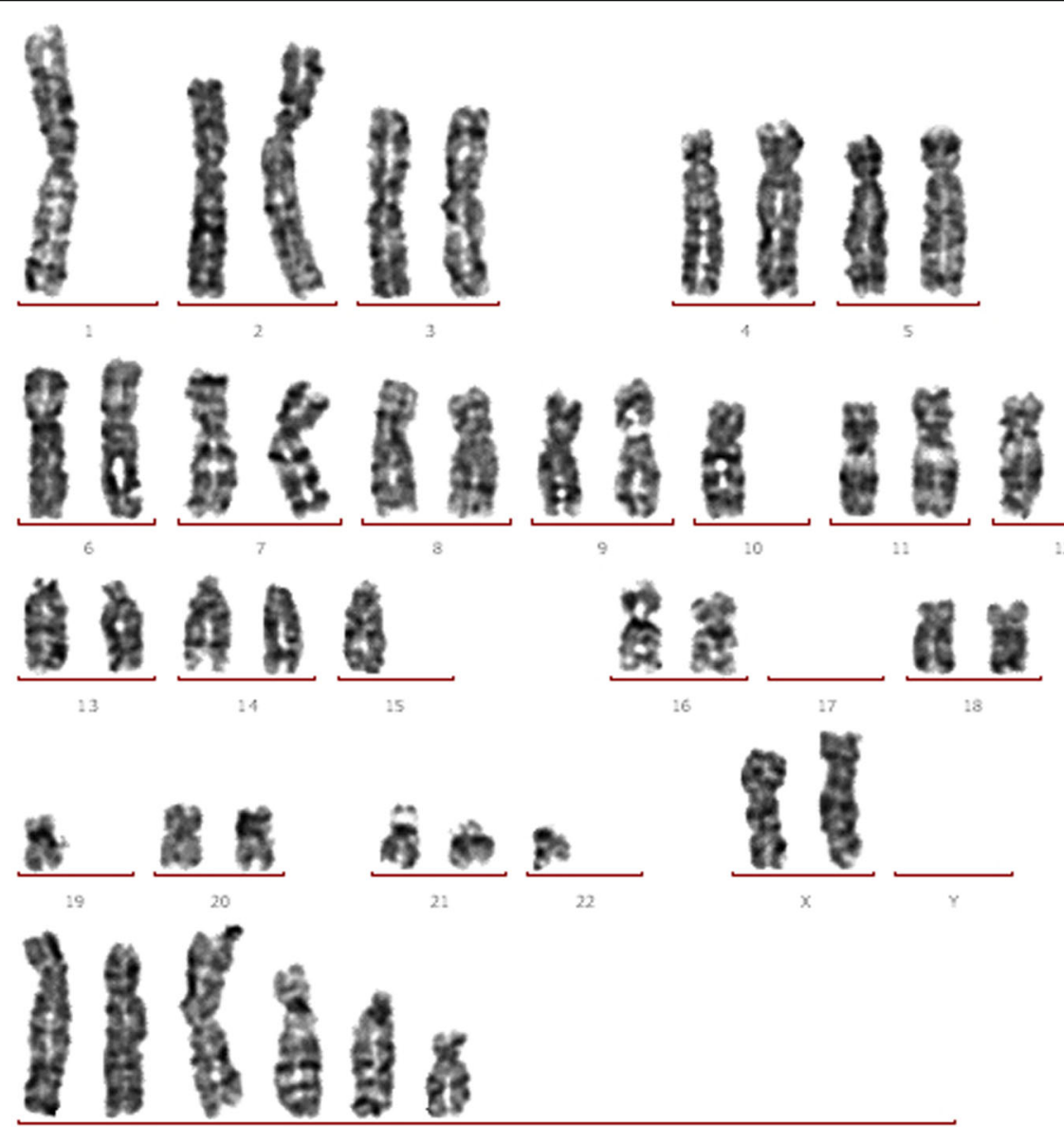

Fig. 4 Karyotype of FDOV1 (18th generation). The additional chromosomes listed in the lowest group have severe structural abnormality, including complex translocation and deletion. It is so difficult to identify the chromosomes that we present them in the lowest group 

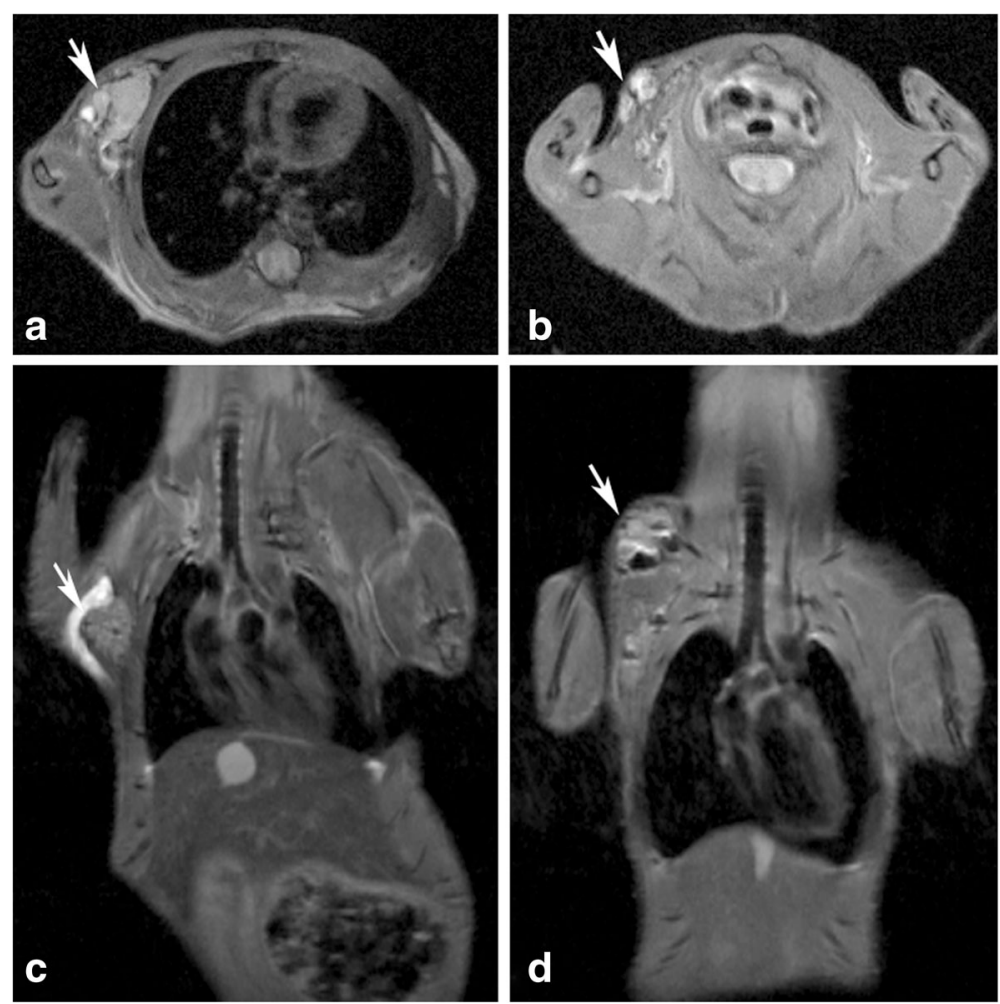

Fig. 5 Magnetic resonance imaging of two transplanted tumors. a and c showed the horizontal plane and coronal plane of one transplanted tumor, respectively, $\mathbf{b}$ and $\mathbf{d}$ showed the horizontal plane and coronal plane of the other transplanted tumor. The tumors in the dorsal flank were pointed out by arrows

H1047R mutation and ARID1A frameshift mutations (p.L2106 fs, p.N201 fs), which are viewed as the most important gene variations in OCCC. In addition, Both of them were found to carry SPOP (p.D82H, c.G244 T), ZNF217 (p.T985I, c.C2954T) and ARID1B (p.E1681X, c.G5041 T) mutations (Table 1), which were further validated by Sanger Sequencing (Fig. 8). Besides, Fig. 7b showed the CNV of tissue block and FDOV1. We observed that somatic copy number was increased in ZNF217(chr.20) and MYC(chr.8), which were reported as frequent amplifications in OCCC [26, 27], as well as MCL1(chr.1), RAD51(chr.15), DOT1L(chr.19), while copy number was decreased in TP53(chr.17), which was documented as a common copy number variant in OCCC [26], as well as NRAS(chr.1), AURKB(chr.17), STK11(chr.19) and CRLF2(chr.X) (Table 2).

\section{Discussion}

Ovarian clear cell carcinoma, as a subtype with distinct clinical behavior, is notorious for its poor survival and

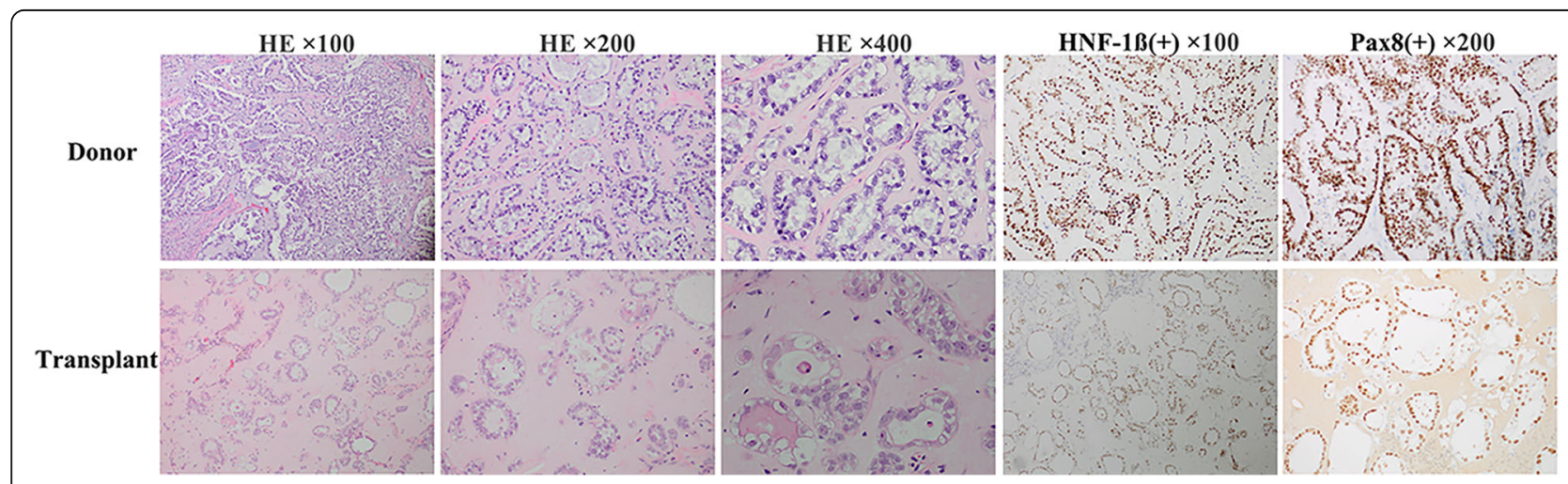

Fig. 6 Histology and immunohistochemistry of FDOV1 cell, donor tumor and transplanted tumor 


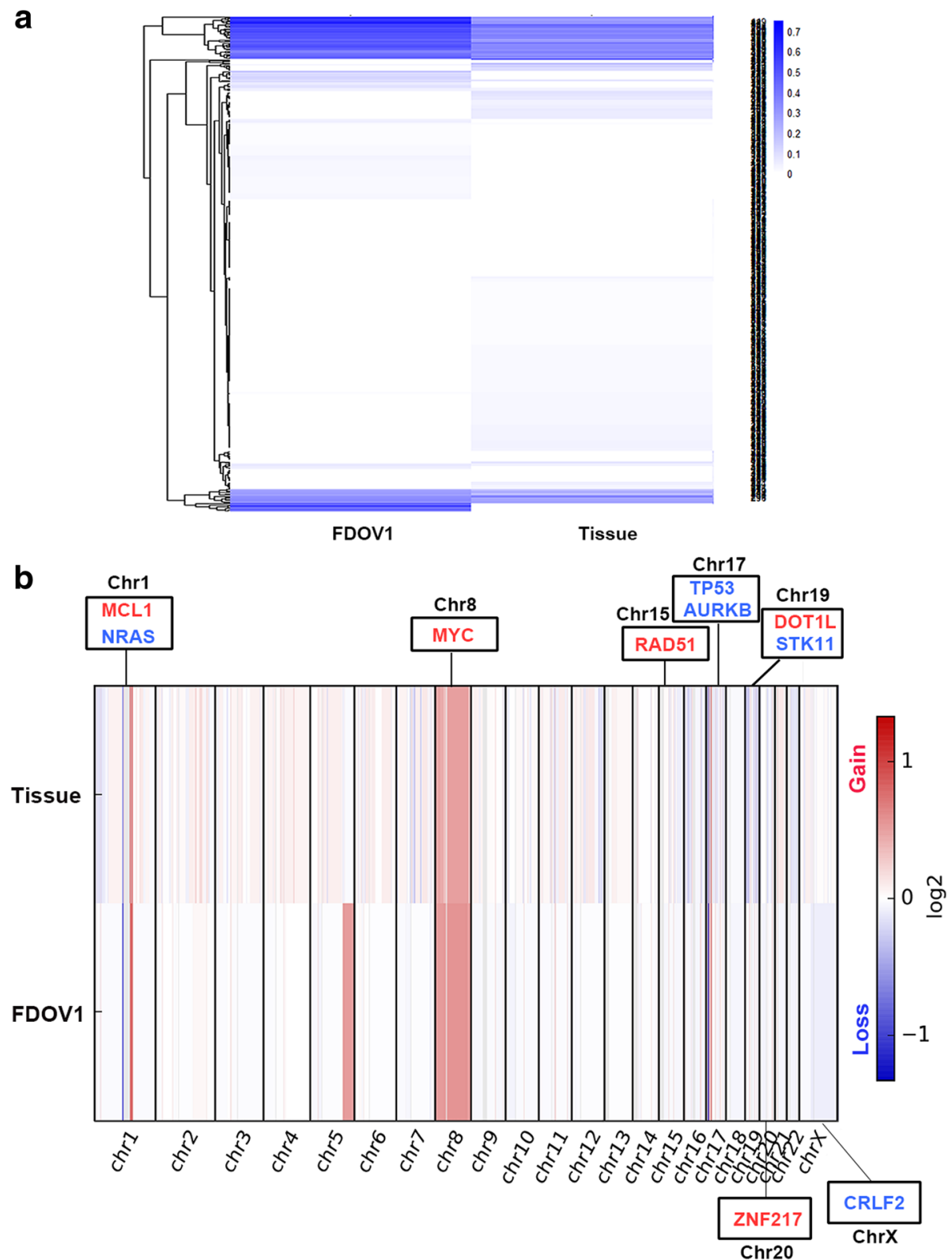

Fig. 7 The results of whole-exome sequencing of FDOV1 and patient's tumor tissue block. a. Somatic variation of FDOV1 and tumor tissue. b. Copy number analysis in FDOV1 and tissue. The genes in red mean copy number gain, the genes in blue mean copy number loss

resistance to conventional platinum-based chemotherapy. An international phase III clinical trial was conducted to investigate the addition of irinotecan as adjuvant chemotherapy for patients with advanced-stage [28]. Unfortunately, no significant survival benefit was found. Given the limited benefit from cytotoxic drugs, there is now great interest in the development of molecular targeted therapy, which requires investigation of a number of areas in the laboratory [3]. Better understanding of the underlying molecular mechanism is of importance.

According to documentations, there were 16 ovarian clear cell carcinoma cell lines reported so far, in addition, TOV-21G, ES-2, which are commercially available from American Tissue Culture Center, and FDOV1. Their characteristics were compared in Table 3. Firstly, most of the OCCC cell lines were from Japan, while FDOV1 is the only one derived from a Chinese mainland woman. It has been demonstrated that the same kind of carcinoma from different race even country tends to have distinct characteristics, especially genetic characteristics [29-31]. We postulated that genetic background might be partly the reason for the marked geographic difference in OCCC. Therefore, the establishment and characterization of a novel 
Table 1 Single nucleotide variant (SNV) of FDOV1 by wholeexome sequencing(WES)

\begin{tabular}{|c|c|c|c|}
\hline Gene & Pdot & Tissue & FDOV1 \\
\hline PIK3CA & p.H1047R & 0.372 & 0.369 \\
\hline SPOP & p.D82H & 0.36 & 0.5 \\
\hline ZNF217 & p.T985I & 0.329 & 0.46 \\
\hline ARID1A & p.L2106 fs & 0.285 & 0.311 \\
\hline ARID1B & p.E1681X & 0.277 & 0.588 \\
\hline ARID1A & p.N201 fs & 0.271 & 0.339 \\
\hline FOXP1 & p.S650delinsIS & 0.081 & \\
\hline $\mathrm{NOTCH} 2$ & p.P6fs & 0.081 & \\
\hline KMT2C & p.K2797 fs & 0.048 & \\
\hline MAP3K1 & p.941_942del & 0.039 & \\
\hline TGFBR2 & p.E125fs & 0.034 & \\
\hline KMT2C & p.T820I & 0.033 & \\
\hline ABL1 & p.605_605del & 0.029 & \\
\hline ROCK2 & p.R1295G & 0.026 & \\
\hline KMT2D & $\mathrm{c} .8366+1 \mathrm{G}>\mathrm{T}$ & 0.02 & \\
\hline ERBB4 & p.G565 V & 0.017 & \\
\hline KMT2C & p.D319Y & 0.014 & \\
\hline CTNNA1 & p.M721 fs & 0.013 & \\
\hline KMT2C & p.R4418S & & 0.028 \\
\hline KMT2D & p.3860_3861del & & 0.02 \\
\hline RNF43 & p.R145L & & 0.018 \\
\hline KMT2A & p.A1253S & & 0.012 \\
\hline
\end{tabular}

cell line derived from Chinese patients is of significance. Secondly, all cell lines were derived from ovary $(10 / 19)$, ascites $(6 / 19)$, and metastatic or recurrent site (3/19), which implied good materials for primarily culture. Lastly, as previously mentioned, ARID1A and PIK3CA mutations are the two most commonly reported. Interestingly, it is found that ARID1A-PIK3CA mutational co-occurrence (33\%) is very high in ovarian CCC [11]. Research work by Chandler et al. supported that a genetic epistasis model wherein ARID1A and PIK3CA mutations cooperate and ovarian cancer can arise only when these genes are co-mutated in the mouse ovarian surface epithelium [11]. Coexistent ARID1A-PIK3CA mutations might be a major driver of OCCC in humans. Among 19 OCCC cell lines, only FDOV1 and TOV-21G carried coexistent ARID1A-PIK3CA mutations. The character of concurrent ARID1A-PIK3CA mutations of FDOV1 might help to better understand the underlying mechanism and even to explore the activity of dual inhibitors in vitro. However, the cell lines established before 2000 lack genetic information due to testing techniques. Besides, some new molecular features found by WES in FDOV1 requires more attentions.

Notably, SPOP, a relatively new gene regulating DNA damage repair, is the most frequently mutated gene in prostate carcinoma [32, 33]. Mutations in SPOP lead to genomics instability and are identified as driver events resulting in tumorigenesis of prostate carcinoma via coordination with $\mathrm{PI} 3 \mathrm{~K} / \mathrm{mTOR}$ and AR (Androgen Receptor) pathway in mouse [34, 35]. Studies on SPOP mutation in other solid carcinomas is reported in follicular and papillary thyroid cancers [36, 37], endometrial clear cell carcinoma [38, 39], gynecological carcinosarcoma [40], lung cancer [41], and colorectal cancer [42]. What is worthy of mentioning is that SPOP mutation in gynecological malignant tumor is not uncommon (18\% in endometrial clear cell carcinoma, $14 \%$ in carcinosarcoma) [38, 40]. In OCCC, the mutation rate of SPOP is $11.1 \%(1 / 9)$ according to COSMIC (Catalogue Of Somatic Mutations In Cancer) database. However, few relevant functional studies are documented in OCCC. Thus, FDOV1, a novel cell line harbored SPOP mutation, is an ideal tool for functional study. In addition, it is suggested that SPOP mutation might represent sensitivity to DNA damaging agents such as PARP inhibitor in prostate carcinoma [35]. Consequently, whether it is indicated a similar effect on OCCC still needs further investigation.

Chromosome 20q13 ZNF217 (Zinc Finger Protein 217) locus amplification, which has found in FDOV1, is one of common molecuclar genetic aberrations in OCCC [43]. The frequency is reported from 20 to $36 \%[10,43,44]$. It is reported that ZNF217 amplification often coexisted with loss of ARID1A expression and PIK3CA mutation [10]. Importantly, ZNF217 amplification has a correlation with shorter worse survival outcome in OCCC, and multivariate analysis suggest it is an independent prognostic factor of PFS (Progression-Free Survival) and OS (Overall survival) [43]. Still, ZNF217 amplification has an adverse prognostic implication in breast and gastric cancer [45-47]. However, the underlying mechanism is still tensely studied. FDOV1 will be an good cell line for mechanism research in vitro.

\section{Conclusions}

An ovarian clear cell carcinoma cell line named FDOV1 was established from a Mainland Chinese patient. FDOV1 showed fast and unlimited multiplication until now and tumorigenicity in vivo. In addition, WES showed that it harbors concurrent ARID1A-PIK3CA mutations and SPOP mutation, also with ZNF217 amplification, which will be an ideal tool for mechanism research of ovarian clear cell carcinoma. 
PIK3CA p.H1047R(c.A3140G)

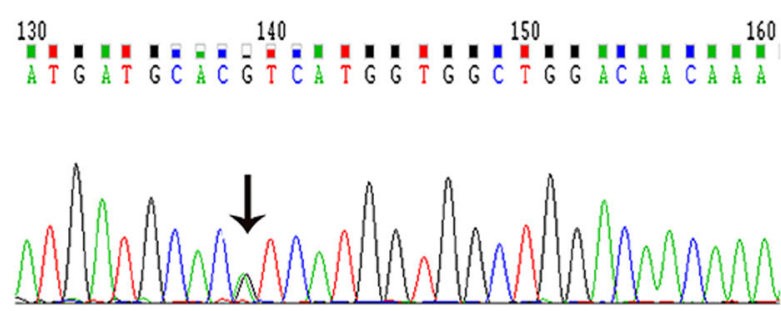

ZNF217 p.T985I (c.C2954T)

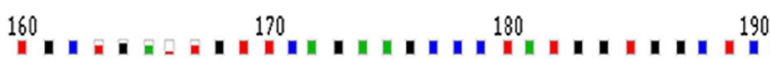
TGCTGATTGTTCAGAAGCCCTATGGTGGCTC

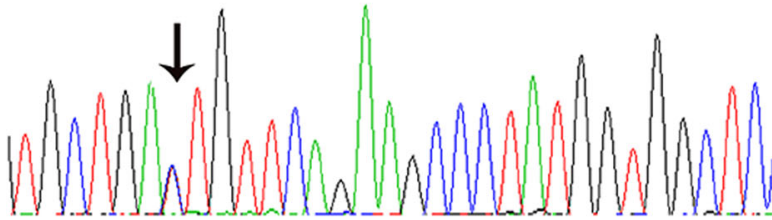

ARID1A p.N201fs (c.602_603delCT)

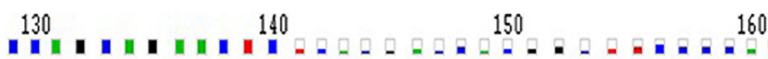

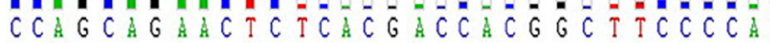

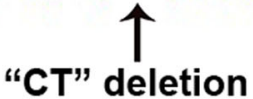

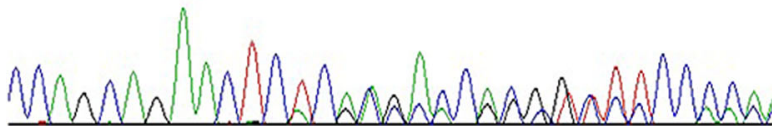

Fig. 8 Sanger sequencing of single nucleotide variant (SNV) in FDOV1

Table 2 Copy number variant (CNV) of FDOV1 by whole-exome sequencing (WES)

\begin{tabular}{llll}
\hline & Chr & Tissue & FDOV1 \\
\hline $\begin{array}{llll}\text { Upregulated Genes } \\
\text { ZNF217 }\end{array}$ & chr20 & 0.75 & 0.91 \\
MYC & chr8 & 0.50 & 0.89 \\
DOT1L & chr19 & 0.78 & 1.12 \\
MCL1 & chr1 & 0.48 & 0.77 \\
RAD51 & chr15 & 0.47 & 0.94 \\
Downregulated Genes & & & \\
NRAS & chr1 & -0.65 & -1.01 \\
TP53 & chr17 & -0.55 & -1.04 \\
AURKB & chr17 & -0.55 & -1.04 \\
STK11 & chr19 & -0.64 & -1.05 \\
CRLF2 & chrX & -1.38 & -1.41 \\
\hline
\end{tabular}

The number in column of tissue and FDOV1 represent the log2 (sample/ germline), consequently, the number more than 0 suggests amplified in copy number, less than 0 suggests decreased in copy number

\section{SPOP p.D82H (c.G244T)}

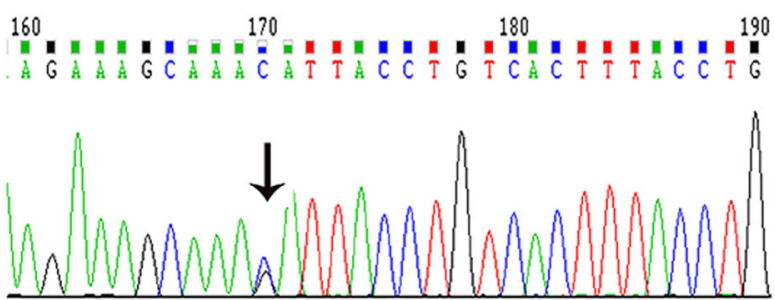

ARID1B p.E1681X (c.G5041T)

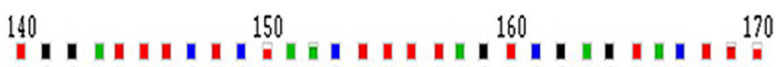
$T G G A T T T C T C T A B C T T T T A G T C G A G T A C T T T$

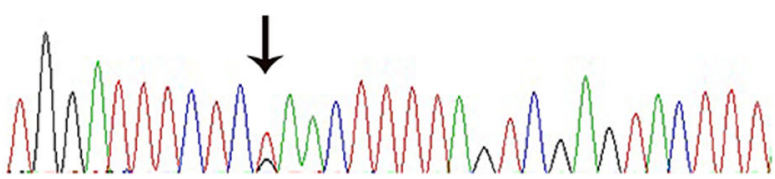

ARID1A p.L2106fs (c.6317_6318delG)

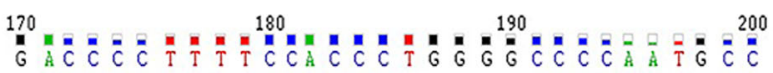

"G" deletion

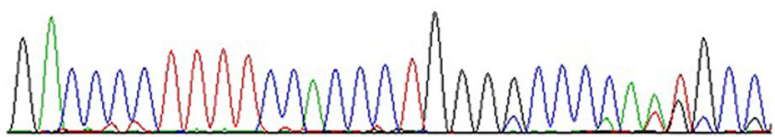

\section{Methods}

Medical history

A 67-year-old woman was admitted into Fudan University Shanghai Cancer Center with the chief complaint of palpable abdominal mass in May 2016. Ultrasound revealed a large pelvic mass $(14 \times 10 \mathrm{~cm})$ with mixed components and a hyperechoic mural nodule $(4 \times 3 \mathrm{~cm})$. Serum tumor markers including carbohydrate antigen (CA) 125 and CA199 were not elevated. Intraoperative findings were only significant for a cystic-and-solid mass $(15 \mathrm{~cm}$ in diameter) in the left adnexa. Frozen pathology was highly suspicious of ovarian clear cell carcinoma. The patient underwent comprehensive staging surgery and the final stage was FIGO (International Federation of Gynecology and Obstetrics) Ia. She gave written informed consent before surgery according to institutional guideline (FUSCC 050432-4-1212B). Six cycles of TC regimen (paclitaxel + carboplatin) chemotherapy were administered. She was followed up every 3 months after treatment. The patient was admitted into outside hospital with chief complain of 
Table 3 Cell lines of ovary clear cell carcinoma

\begin{tabular}{|c|c|c|c|c|c|c|c|c|}
\hline & Cell line & Country & Age & Material & DT & $\begin{array}{l}\text { Chromosome } \\
\text { number }\end{array}$ & Transplantability & Gene characteristics \\
\hline 1 & HUOCA-II (1987) & Japan & 51 & Ovary & 24,28 & 46 & Yes & \\
\hline 2 & RMG-I (1988) & Japan & 34 & Ascites & 60 & 47 & Yes & \\
\hline 3 & OCC1 (1990) & Hong Kong & 47 & Ascites & 36,38 & $70-77$ & Yes & \\
\hline 4 & RMG-II (1991) & Japan & 53 & Ascites & 58 & hypertetraploid & No & \\
\hline 5 & TOV-21G(1991) & $\begin{array}{l}\text { French-Canadian } \\
\text { descent }\end{array}$ & 62 & Ovary & 36 & 47 & Yes & $\begin{array}{l}\text { ARID1A p.Q758fs }{ }^{a} 75, \text { ARID1A } \\
\text { p.Y551fs } 72, \text { KRAS p.G13C, } \\
\text { PIK3CA p.H1047Y }\end{array}$ \\
\hline 6 & $\mathrm{ES}-2(1991)^{\mathrm{a}}$ & Black & 47 & Ovary & 24 & $66-88$ & Yes & BRAF p.V600E, MAP2K1 p.D67N \\
\hline 7 & OVISE (1995) & Japan & 40 & Metastatic tumor & $60-70$ & $59-65$ & Yes & \\
\hline 8 & OVTOKO (1995) & Japan & 78 & Metastatic tumor & $60-70$ & $76-83$ & Yes & \\
\hline 9 & JHOC-5 (1999) & Japan & 47 & Ovary & 52 & $74-85$ & No & \\
\hline 10 & JHOC-6 (1999) & Japan & 43 & Recurrent tumor & 70 & $46-49$ & Yes & \\
\hline 11 & SMOV-2 (1999) & Japan & 46 & Ovary & 48.2 & $85-92$ & Yes & P53 mutation (-) \\
\hline 12 & TAYA (2002) & Japan & 43 & Ascites & 50 & $69-74$ & No & $\begin{array}{l}\text { P53 mutation (codon } 132 \text { in exon 5), } \\
\text { PTEN mutation(-) }\end{array}$ \\
\hline 13 & RMG-V (2005) & Japan & 52 & Ascites & 15.5 & $77-85$ & No & \\
\hline 14 & TU-OC-1 (2013) & Japan & 65 & Ovary & 38.4 & $64-90$ & Yes & PIK3CA E542K mutation \\
\hline 15 & TU-OC-2(2016) & Japan & 68 & Ovary & 37.5 & $41-96$ & No & $\begin{array}{l}\text { PIK3CA mutation (-), TP53 mutation (-) } \\
\text { ARID1A loss }\end{array}$ \\
\hline 16 & $\mathrm{HCH}-1$ (2016) & Japan & 67 & Ovary & $48.7,66.4$ & $39-44$ & Yes & $\begin{array}{l}\text { PIK3CA mutation (-), P53 mutation(-), } \\
\text { PTEN mutation(-), KRAS mutation(-) }\end{array}$ \\
\hline 17 & NOCC(2016) & Japan & 48 & Ascites & 29 & $60-83$ & Yes & \\
\hline 18 & $\mathrm{HCH}-3$ (2017) & Japan & 41 & Ovary & 82 & $78-87$ & Yes & KRAS mutation (+), TP53 mutation(+) \\
\hline 19 & FDOV1(2017) & China mainland & 67 & Ovary & 37.4 & $45-90$ & Yes & $\begin{array}{l}\text { PIK3CA p.H1047R, ARID1A p.L2106 fs, } \\
\text { ARID1A p.N201 fs, SPOP p.D82H } \\
\text { ARID1B p.E1681X }\end{array}$ \\
\hline
\end{tabular}

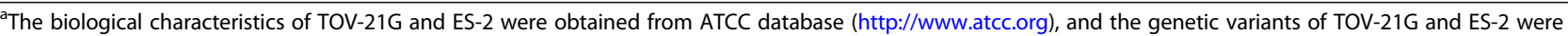
obtained from COSMIC database (https://cancer.sanger.ac.uk/cell_lines), which provide more detailed and complete genetic features of cell lines

intestinal obstruction in May 2017. She developed multiple sites of venous thromboembolism and cerebral infarction. Unfortunately, she died 1 month later with no chance of anti-cancer treatment.

\section{Establishment of cell line}

The fresh tissue $\left(1 \mathrm{~cm}^{3}\right)$ from primary ovarian tumor was obtained during comprehensive staging surgery, and suspended in phosphate buffer solution (PBS) to get rid of necrotic and connective tissue. The material was then finely minced into $1-\mathrm{mm}^{3}$ tissue blocks and placed in 10-cm cell culture dishes (Corning, NY, USA) containing Medium 199 medium (HyClone, Thermo Scientific, USA) with $10 \%$ fetal bovine serum (Gibco, Life technologies, USA), $100 \mathrm{IU} / \mathrm{ml}$ penicillin (HyClone, Thermo Scientific, USA) and $50 \mu \mathrm{g} / \mathrm{ml}$ streptomycin (HyClone, Thermo Scientific, USA). The cells were then incubated in a humidified atmosphere containing $5 \% \mathrm{CO} 2$ at $37^{\circ} \mathrm{C}$. After repeated passage, a new cell line of FDOV1 was successfully established with more than 80 generations.
FDOV1 cells have been sent to China General Microbiological Culture Collection Center for preservation (No. 13812) in March 2017.

\section{Growth characteristics}

Cell proliferation and growth curve was determined by Cell Counting Kit-8 (CCK- 8$)$ test. FDOV1 cells $\left(2 \times 10^{3}\right.$ cells $/ 100 \mu \mathrm{l}$ ) were seeded in 96 -well plates in sextuplicate. Ten days later, $100 \mu \mathrm{l}$ mixture (CCK-8/medium 1:9) were added into the wells for incubation by 2 hours. We then measured the Optical Density (OD) at $450 \mathrm{~nm}\left(\mathrm{OD}_{450}\right)$ by a microplate reader (Synergy H4, Bio-Tek).

\section{Cell cycle analysis by flow cytometry}

Resuspended FDOV1 cells $\left(1 \times 10^{6}\right.$ cell $)$ were kept overnight in $3 \mathrm{ml} 75 \%$ ethanol at $-20{ }^{\circ} \mathrm{C}$. After treatment, the cells were collected and stained with propidium iodide solution for $20 \mathrm{~min}$ at $4{ }^{\circ} \mathrm{C}$ in darkness. We then assessed the cell cycle by flow cytometer (BD Biosciences, San Jose, CA, USA). 


\section{Chromosome analysis}

The cells in exponential phase were treated with $0.25 \mu \mathrm{g} / \mathrm{ml}$ colchicine for 6 hours and kept overnight at $37{ }^{\circ} \mathrm{C}$. We then treated the cells with $0.1 \%$ trypsin solution for $15 \mathrm{~s}$ at room temperature and stained them with 3\% Giemsa for G-band karyotyping. After examing 45 metaphases, the histograms of the chromosomal distribution were determined.

\section{Tumor markers}

A total of $2 \times 10^{6}$ cells were cultured for 4 days in total. The medium was changed and collected every 2 days, then were sent for tumor marker detection by chemiluminescence immunoassay. Detected markers included CA 125, CA 199, CA 153, CA 724, AFP, CEA and HE4.

\section{Heterotransplantation}

All the procedures were approved by the Department of Laboratory Animal Science in Fudan University. For in vivo studies, 4-6 weeks old NOD/SCID mice (Shanghai SLAC Laboratory Animal, Shanghai, China) were maintained under sterile conditions. FDOV1 cells $\left(1 \times 10^{7}\right.$ cells, passage 18) were injected subcutaneously into the dorsal flanks of two mice. Visible tumors were noted in both mice 20 days after transplantation.

\section{Histological analysis and immunohistochemistry}

Transplant tumors were fixed in $10 \%$ buffered formalin for $24 \mathrm{~h}$ and embedded in paraffin. Hematoxylin and eosin (HE) were used to stain 4- $\mu \mathrm{m}$ sections. The markers used for immunohistochemistry were listed as follows: HNF-1 $\beta$ (Sigma, CA, USA), Napsin A (Abcam, Cambridge, UK), Pax-8 (Cellmarque, CA, USA), ER (Roche, Basel, Swiss) and PR (Roche, Basel, Swiss). Microscopic slides were reviewed by a senior gynecology-dedicated pathologist (Prof. Yang).

\section{Whole-exome sequencing (WES) of FDOV1 cell and patient's tumor tissue}

The WES was performed by 3D Medicines Corporation and the specific method was the same as a previous publication [48].

\section{Sanger sequencing}

Mutations of the specific genes in FDOV1 cells were validated by Sanger Sequencing. The RNA was extracted by Trizol Methods, then reverse transcription polymerase chain reaction (RT-PCR) was performed as our previous study [49]. The primers were showed in Additional file 1: Table S1. PCR amplification was performed as follows: denaturation at $98{ }^{\circ} \mathrm{C}$ for $5 \mathrm{~min}$, 30 cycle of $98{ }^{\circ} \mathrm{C}$ for $10 \mathrm{~s}, 58{ }^{\circ} \mathrm{C}$ for 30 s, and $72{ }^{\circ} \mathrm{C}$ for $1 \mathrm{~min}$, then holding at $72{ }^{\circ} \mathrm{C}$ for $1 \mathrm{~min}$, finally incubation at $4{ }^{\circ} \mathrm{C}$. Sequencing was performed at Boshang Biotechnology Co.Ltd. (Shanghai, China).

\section{Additional files}

Additional file 1: Table S1. The primer of Sanger sequence for specific genes mutation in FDOV1. (DOCX $15 \mathrm{~kb}$ )

\section{Abbreviations}

AFP: Alpha fetoprotein; ARID1A: AT-Rich Interactive Domain-containing protein 1A; CA125: Carbohydrate antigen125; CA199: Carbohydrate antigen 199; CEA: Carcinoembryonic antigen; HE4: Human epididymis protein 4; OCCC: Ovarian clear cell carcinoma; PIK3CA: Phosphoinositide-3-kinase Catalytic Alpha; FIGO: International Federation of Gynecology and Obstetrics; TC: Paclitaxel \& Carboplatin; PBS: Phosphate buffer solution; CCK8: Cell counting kit-8; OD450: Optical density (OD) at 450 nm; HE: Hematoxylin and eosin; MRI: Magnetic resonance imaging; WES: Whole-exome sequence; SNV: Single nucleotide variant; CNV: Copy number variation; indel: Insertion and deletion; ER: Estrogen receptor; AR: Androgen receptor; PR: Progesterone receptor; ZNF217: Zinc Finger Protein 217; PFS: Progression-Free Survival;

OS: Overall survival

\section{Acknowledgements \\ We thank Dr. David Chan for his advice in manuscript preparation. We thank 3D Medicines Corporation for WES analysis.}

\section{Funding}

The study was supported by grants from National Natural Science Foundation of China (81572803 and 81702558).

\section{Availability of data and materials}

All data generated or analyzed during this study are included in this published article.

\section{Authors' contributions}

$H Y$ and $L X$ treated the patient and collected clinicopathological data. WJ and LX were involved in sample collection, processing and cell culture. WJ, TH and XP studied the biological and molecular characteristics of the cell lines as well as its tumorigenicity. WY performed the histological examination and immunohistological staining of the surgical tissues, cell cultures and tumors from transplants. LG measured tumor markers. HY and WJ analyzed and interpreted the data of the patients, cell line and the transplant. SY was a major contributor in writing the manuscript and HY finalized the paper. All authors read and approved the final manuscript.

Ethics approval and consent to participate

The patient gave written informed consent before surgery according to institutional guideline (FUSCC 050432-4-1212B).

Consent for publication

Institutional consent form was written before surgery.

Competing interests

The authors declare that they have no competing interests.

\section{Publisher's Note}

Springer Nature remains neutral with regard to jurisdictional claims in published maps and institutional affiliations.

\section{Author details}

${ }^{1}$ Department of Gynecologic Oncology, Fudan University Shanghai Cancer Center, Shanghai 200032, China. '2Department of Pathology, Fudan University Shanghai Cancer Center, Shanghai 200032, China. ${ }^{3}$ Department of Oncology, Shanghai Medical College, Fudan University, Shanghai 200032, China.

${ }^{4}$ Department of Clinical Laboratory, Fudan University Shanghai Cancer Center, Shanghai 200032, China. 
Received: 11 December 2017 Accepted: 27 June 2018 Published online: 09 July 2018

\section{References}

1. Anglesio MS, Carey MS, Kobel M, Mackay H, Huntsman DG. Clear cell carcinoma of the ovary: a report from the first ovarian clear cell symposium, June 24th, 2010. Gynecol Oncol. 2011;121(2):407-15.

2. del Carmen MG, Birrer M, Schorge JO. Clear cell carcinoma of the ovary: a review of the literature. Gynecol Oncol. 2012;126(3):481-90.

3. Okamoto A, Glasspool RM, Mabuchi S, Matsumura N, Nomura H, Itamochi H, et al. Gynecologic Cancer InterGroup (GCIG) consensus review for clear cell carcinoma of the ovary. Int J Gynecol Cancer. 2014;24(9 Suppl 3):S20-5.

4. Sung $\mathrm{PL}$, Chang $\mathrm{YH}$, Chao KC, Chuang CM. Global distribution pattern of histological subtypes of epithelial ovarian cancer: a database analysis and systematic review. Gynecol Oncol. 2014;133(2):147-54.

5. Jones S, Wang TL, Shih le M, Mao TL, Nakayama K, Roden R, et al. Frequent mutations of chromatin remodeling gene ARID1A in ovarian clear cell carcinoma. Science. 2010;330(6001):228-31.

6. Wiegand KC, Shah SP, Al-Agha OM, Zhao Y, Tse K, Zeng T, et al. ARID1A mutations in endometriosis-associated ovarian carcinomas. N Engl J Med. 2010;363(16):1532-43.

7. Campbell IG, Russell SE, Choong DY, Montgomery KG, Ciavarella ML, Hooi CS, et al. Mutation of the PIK3CA gene in ovarian and breast cancer. Cancer Res. 2004;64(21):7678-81.

8. Kuo KT, Mao TL, Jones S, Veras E, Ayhan A, Wang TL, et al. Frequent activating mutations of PIK3CA in ovarian clear cell carcinoma. Am J Pathol. 2009;174(5):1597-601.

9. Yamamoto S, Tsuda H, Takano M, Tamai S, Matsubara O. Loss of ARID1A protein expression occurs as an early event in ovarian clear-cell carcinoma development and frequently coexists with PIK3CA mutations. Mod Pathol. 2012;25(4):615-24.

10. Huang HN, Lin MC, Huang WC, Chiang YC, Kuo KT. Loss of ARID1A expression and its relationship with PI3K-Akt pathway alterations and ZNF217 amplification in ovarian clear cell carcinoma. Mod Pathol. 2014; 27(7):983-90.

11. Chandler RL, Damrauer JS, Raab JR, Schisler JC, Wilkerson MD, Didion JP, et al. Coexistent ARID1A-PIK3CA mutations promote ovarian clear-cell tumorigenesis through pro-tumorigenic inflammatory cytokine signalling. Nat Commun. 2015:6:6118.

12. Yamada T, Hattori K, Satomi H, Okazaki T, Mori H, Hirose Y. Establishment and characterization of a cell line $(\mathrm{HCH}-1)$ originating from a human clear cell carcinoma of the ovary. J Ovarian Res. 2016;9(1):32.

13. Ishiwata I, Ishiwata C, Soma M, Ishikawa H. Establishment of HUOCA-II, a human ovarian clear cell adenocarcinoma cell line, and its angiogenic activity. J Natl Cancer Inst. 1987;78(4):667-73.

14. Nozawa S, Tsukazaki K, Sakayori M, Jeng CH, lizuka R. Establishment of a human ovarian clear cell carcinoma cell line (RMG-I) and its single cell cloning-with special reference to the stem cell of the tumor. Hum Cell. 1988;1(4):426-35.

15. Nozawa S, Yajima M, Sasaki H, Tsukazaki K, Aoki D, Sakayori M, et al. A new CA125-like antigen (CA602) recognized by two monoclonal antibodies against a newly established ovarian clear cell carcinoma cell line (RMG-II). Jpn J Cancer Res. 1991;82(7):854-61.

16. Gorai I, Nakazawa T, Miyagi E, Hirahara F, Nagashima Y, Minaguchi H. Establishment and characterization of two human ovarian clear cell adenocarcinoma lines from metastatic lesions with different properties. Gynecol Oncol. 1995;57(1):33-46.

17. Yamada K, Tachibana T, Hashimoto H, Suzuki K, Yanagida S, Endoh H, et al. Establishment and characterization of cell lines derived from serous adenocarcinoma (JHOS-2) and clear cell adenocarcinoma (JHOC-5, JHOC-6) of human ovary. Hum Cell. 1999;12(3):131-8.

18. Yonamine $\mathrm{K}$, Hayashi $\mathrm{K}$, lida T. Establishment and characterization of human ovarian clear cell adenocarcinoma cell line (SMOV-2), and its cytotoxity by anticancer agents. Hum Cell. 1999;12(3):139-48.

19. Saga $Y$, Suzuki M, Machida S, Ohwada M, Sato I. Establishment of a new cell line (TAYA) of clear cell adenocarcinoma of the ovary and its radiosensitivity. Oncology. 2002;62(2):180-4.

20. Aoki D, Suzuki N, Susumu N, Noda T, Suzuki A, Tamada Y, et al. Establishment and characterization of the RMG-V cell line from human ovarian clear cell adenocarcinoma. Hum Cell. 2005;18(3):143-6.
21. Itamochi $H$, Kato M, Nishimura M, Oumi N, Oishi T, Shimada M, et al. Establishment and characterization of a novel ovarian clear cell adenocarcinoma cell line, TU-OC-1, with a mutation in the PIK3CA gene. Hum Cell. 2013;26(3):121-7.

22. Sato S, Itamochi H, Oumi N, Chiba Y, Oishi T, Shimada M, et al. Establishment and characterization of a novel ovarian clear cell carcinoma cell line, TU-OC-2, with loss of ARID1A expression. Hum Cell. 2016;29(4):181-7.

23. Wong WS, Wong YF, Ng YT, Huang PD, Chew EC, Ho TH, et al. Establishment and characterization of a new human cell line derived from ovarian clear cell carcinoma. Gynecol Oncol. 1990;38(1):37-45.

24. Ohyama A, Toyomura J, Tachibana T, Isonishi S, Takahashi H, Ishikawa H. Establishment and characterization of a clear cell carcinoma cell line, designated NOCC, derived from human ovary. Hum Cell. 2016;29(4):188-96.

25. Yamada T, Hattori K, Satomi H, Okazaki T, Moriand H, Hirose Y. Characterization of a novel cell line $(\mathrm{HCH}-3)$ derived from a human ovarian clear cell carcinoma. J Carcinog Mutagen. 2017;8(3):292.

26. Murakami R, Matsumura N, Brown JB, Higasa K, Tsutsumi T, Kamada M, et al. Exome sequencing landscape analysis in ovarian clear cell carcinoma shed light on key chromosomal regions and mutation gene networks. Am J Pathol. 2017;187(10):2246-58.

27. Kim SI, Lee JW, Lee M, Kim HS, Chung HH, Kim JW, et al. Genomic landscape of ovarian clear cell carcinoma via whole exome sequencing. Gynecol Oncol. 2018;148(2):375-82.

28. Sugiyama T, Okamoto A, Enomoto T, Hamano T, Aotani E, Terao Y, et al. Randomized phase III trial of irinotecan plus cisplatin compared with paclitaxel plus carboplatin as first-line chemotherapy for ovarian clear cell carcinoma: JGOG3017/GCIG trial. J Clin Oncol Off J Am Soc Clin Oncol. 2016;34(24):2881-7.

29. Lai Y, Wang C, Civan JM, Palazzo JP, Ye Z, Hyslop T, et al. Effects of Cancer stage and treatment differences on racial disparities in survival from Colon Cancer: a United States population-based study. Gastroenterology. 2016; 150(5):1135-46.

30. Goutte N, Sogni P, Bendersky N, Barbare JC, Falissard B, Farges O. Geographical variations in incidence, management and survival of hepatocellular carcinoma in a western country. J Hepatol. 2017;66(3):537-44.

31. Keenan T, Moy B, Mroz EA, Ross K, Niemierko A, Rocco JW, et al. Comparison of the genomic landscape between primary breast Cancer in African American versus white women and the Association of Racial Differences with Tumor Recurrence. J Clin Oncol Off J Am Soc Clin Oncol. 2015;33(31):3621-7.

32. Abeshouse A, Ahn J, Akbani R, Ally A, Amin S, Andry CD, et al. The molecular taxonomy of primary prostate cancer. Cell. 2015;163(4):1011-25.

33. Barbieri CE, Baca SC, Lawrence MS, Demichelis F, Blattner M, Theurillat JP, et al. Exome sequencing identifies recurrent SPOP, FOXA1 and MED12 mutations in prostate cancer. Nat Genet. 2012:44(6):685-9.

34. Blattner M, Liu D, Robinson BD, Huang D, Poliakov A, Gao D, et al. SPOP mutation drives prostate tumorigenesis in vivo through coordinate regulation of PI3K/mTOR and AR signaling. Cancer Cell. 2017;31(3):436-51.

35. Boysen G, Barbieri CE, Prandi D, Blattner M, Chae SS, Dahija A, et al. SPOP mutation leads to genomic instability in prostate cancer. Elife. 2015;4:e09207.

36. Yoo SK, Lee S, Kim SJ, Jee HG, Kim BA, Cho H, et al. Comprehensive analysis of the transcriptional and mutational landscape of follicular and papillary thyroid cancers. PLoS Genet. 2016;12(8):e1006239.

37. Ye L, Zhou X, Huang F, Wang W, Qi Y, Xu H, et al. The genetic landscape of benign thyroid nodules revealed by whole exome and transcriptome sequencing. Nat Commun. 2017;8:15533.

38. Le Gallo M, Rudd ML, Urick ME, Hansen NF, Zhang S, Lozy F, et al. Somatic mutation profiles of clear cell endometrial tumors revealed by whole exome and targeted gene sequencing. Cancer. 2017;123(17):3261-8.

39. DeLair DF, Burke KA, Selenica P, Lim RS, Scott SN, Middha S, et al. The genetic landscape of endometrial clear cell carcinomas. J Pathol. 2017; 243(2):230-41.

40. Jones S, Stransky N, McCord CL, Cerami E, Lagowski J, Kelly D, et al. Genomic analyses of gynaecologic carcinosarcomas reveal frequent mutations in chromatin remodelling genes. Nat Commun. 2014;5:5006.

41. Kan Z, Jaiswal BS, Stinson J, Janakiraman V, Bhatt D, Stern HM, et al. Diverse somatic mutation patterns and pathway alterations in human cancers. Nature. 2010;466(7308):869-73.

42. Kim MS, Je EM, Oh JE, Yoo NJ, Lee SH. Mutational and expressional analyses of SPOP, a candidate tumor suppressor gene, in prostate, gastric and colorectal cancers. APMIS. 2013;121(7):626-33. 
43. Rahman MT, Nakayama K, Rahman M, Nakayama N, Ishikawa M, Katagiri A, et al. Prognostic and therapeutic impact of the chromosome 20q13.2 ZNF217 locus amplification in ovarian clear cell carcinoma. Cancer. 2012; 118(11):2846-57.

44. Huang HN, Huang WC, Lin CH, Chiang YC, Huang HY, Kuo KT. Chromosome 20q13.2 ZNF217 locus amplification correlates with decreased E-cadherin expression in ovarian clear cell carcinoma with PI3K-Akt pathway alterations. Hum Pathol. 2014;45(11):2318-25.

45. Littlepage LE, Adler AS, Kouros-Mehr H, Huang G, Chou J, Krig SR, et al. The transcription factor ZNF217 is a prognostic biomarker and therapeutic target during breast cancer progression. Cancer Discov. 2012;2(7):638-51.

46. Bellanger A, Donini CF, Vendrell JA, Lavaud J, Machuca-Gayet I, Ruel M, et al. The critical role of the ZNF217 oncogene in promoting breast cancer metastasis to the bone. J Pathol. 2017;242(1):73-89.

47. Shida A, Fujioka S, Kurihara H, Ishibashi Y, Mitsumori N, Omura N, et al. Prognostic significance of ZNF217 expression in gastric carcinoma. Anticancer Res. 2014:34(9):4813-7.

48. Feng F, Cheng Q, Yang L, Zhang D, Ji S, Zhang Q, et al. Guidance to rational use of pharmaceuticals in gallbladder sarcomatoid carcinoma using patientderived cancer cells and whole exome sequencing. Oncotarget. 2017;8(3): 5349-60.

49. Xiang L, Li J, Jiang W, Shen X, Yang W, Wu X, et al. Comprehensive analysis of targetable oncogenic mutations in chinese cervical cancers. Oncotarget. 2015;6(7):4968-75.

Ready to submit your research? Choose BMC and benefit from:

- fast, convenient online submission

- thorough peer review by experienced researchers in your field

- rapid publication on acceptance

- support for research data, including large and complex data types

- gold Open Access which fosters wider collaboration and increased citations

- maximum visibility for your research: over $100 \mathrm{M}$ website views per year

At BMC, research is always in progress.

Learn more biomedcentral.com/submissions 